\section{Tobacco Free Initiative, ASH Australia, Brown and Williamson, Smoke free children in Ireland, Henley order, Smoke Signals, and smoking among Hong Kong's children}

Web Watch follows issues relevant to tobacco control on the world wide web. The emphasis is on new sites or new features appearing on the web including relevant URLs and short descriptions of the material. A web site is available featuring the URL links referenced in this column as well as those referenced in past columns; the URL for that site is <http://www. gate.net/ jcannon/webwatch/>.

\section{Tobacco Free Initiative home page \\ $<$ http://www.who.int/toh/>}

"Tobacco is a killer. Tobacco should not be advertized, subsidized or glamorized." "WHO cannot remain indifferent. We need to free our population-in particular the young - of the tobacco pandemic." Those pronouncements are the words of Dr Gro Harlem Brundtland, director-general of the World Health Organisa-

Dr Brundtland was not speaking idly. Immediately after assuming the position of directorgeneral from Dr Hiroshi Nakajima, she established a Cabinet project, the Tobacco Free Initiative (TFI), to coordinate an improved global strategic response to tobacco as an important public health issue. The longterm mission is to reduce smoking prevalence and tobacco consumption in all countries and among all groups, and thereby reduce the burden of disease caused by tobacco.

The TFI site features a wide selection of WHO publications relating to tobacco, plus information about TFI including mission, goals, and management.

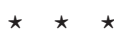

\section{ASH Australia}

$<$ http://www.ashaust.org.au/>

Dedicated to improving tobacco control, ASH Australia provides timely media releases plus facts and issues in tobacco control. Cessation guidance and personal stories from smokers welcome the tobacco industry's victims. An allencompassing set of links to Australian governmental organisations helps the visitor contact their legislator.

A particularly striking poster is available detailing the incompleteness of cigarette pack warnings. To find out what the tobacco companies and your government forgot to tell you, go to:

Web Watch is prepared by fack Cannon. Send him by email (jcannon@gate.net).
Warning: This poster is not for the fainthearted.

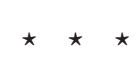
tion (WHO). correspondence to

\section{Brown and Williamson}

$<$ http://www.brownandwilliamson.com>

Claiming to be a "responsible company in a controversial industry", Brown and Williamson has launched this site which the Advocacy Institute has characterised as "a masterstroke of public relations." Although no details are offered on exactly what the company is responsible for, the company does admit that evidence is sufficient to conclude that smoking causes diseases and that low-tar cigarettes may not be any less hazardous than regular brands.

"We've got to face up to reality," said Sharon Boyse, Brown and Williamson's director of scientific communications. "It is a risky product and we understand that some people don't want to take those risks anymore". However no admission of dangers from "nicotine addiction" or "secondhand smoke" can be found on the site-the latter being a subject with which Ms Boyse is well familiar (see "Vast sums of money ... to keep the controversy alive - the 1988 BAT memo" in Tobacco Control 1997;6:236-9). On the subject of addiction Brown and Williamson discusses a "confused definition", while environmental tobacco smoke can be "annoying".

Responding to a perceived need to provide a continuing dialogue with the public, an electronic mail system has been installed. "With the addition of e-mail, we are better positioned to communicate on a personalized basis," says Steve Kottak, manager, public affairs. "The public can get to know our comals' questions and concerns".

Calling the web site a "cruel hoax" that seemed to be drafted by Brown and Williamson's lawyers, John Garrison, chief executive officer of the American Lung Association, said, "This is a very clever defensive maneuver to try to make themselves less

A close analysis of the site supports Mr Garrison's position. Indeed the material parrots the tobacco industry's positions as defendents in the numerous legal suits against them.

The most striking message that comes through is that Brown and Williamson is every pany and we can directly respond to individuliable as future lawsuits arrive". 


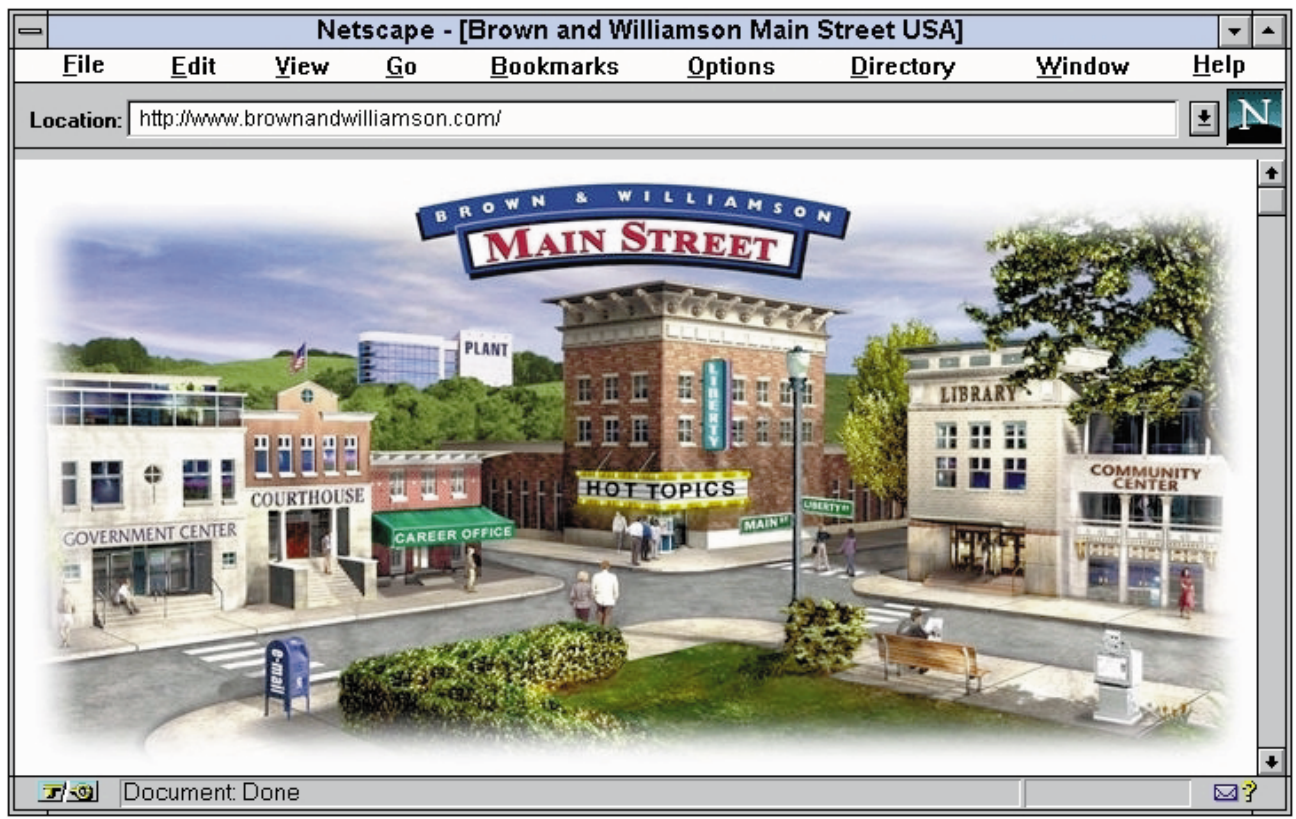

Figure 1 The web site for Brown and Williamson.

bit as adept at producing high-quality graphics (figure 1) as they are at producing high-yield hybrid nicotine plants. Many of the graphic elements found on the web site were inspired by buildings and fixtures in and around the city of Louisville Kentucky, where Brown and Williamson has been headquartered for over 70 years. These graphic elements are actually links to a vast storehouse of information. Some of it is good but most is misleading, self-promoting, or missing key elements.

The Advocacy Institute has produced a superb analysis of the Brown and Williamson site. To access their analysis, go to $<$ <ttp://www.scarcnet.org/alerts/bwwebsite.htm>.

\section{Growing up in smoke}

$<$ http://smoke-free.eire.org/contents.htm>

Produced by the Smoke-Free Leitrim project of the North Western Health Board of Ireland, this enticing site (figure 2 ) is distinctly oriented towards children and their parents.

A song by the Smoke Free Singers can be downloaded. It is in WAV format and should play automatically depending on your browser and soundcard.

The principal message is that children are passive smokers who depend on their parents to protect them from the dangers of secondhand smoke. Easy to understand descriptions are offered on the detrimental effects of cigarette smoke on the heart, lungs, reproductive system, brain, nose, and throat.

Advice to parents on ways to protect their children is available along with information on asthma, bronchitis, pneumonia, and ear infections in children exposed to smoke.

Smoke Free Leitrim is supported by the Health Promotion Unit, the Irish Cancer Society, the Irish Heart Foundation and the Office for Health Gain.

\section{Henley punitive damages}

On 10 February 1999 a jury in San Francisco, California awarded Patricia Henley US $\$ 50$ million in punitive damages for maladies caused by smoking. The award was against Philip Morris. Then on 30 March a jury in Portland, Oregon, also ordered Philip Morris to pay a record $\$ 81$ million award to the family of Jesse Williams who died of lung cancer after smoking Marlboro cigarettes for 40 years.

Of particular significance is an opinion and order issued on 6 April by California superior court judge John E Munter, the presiding judge in the Henley case. Although Judge Munter reduced the Henley punitive damages to $\$ 25$ million, the order is far from being a favourable development for the tobacco industry. Judge Munter clearly agreed with the jury decision but felt obligated to reduce the award to be consistent with case law precedents. However, Judge Munter left no doubt in his support of the jury decision:

"On the one hand, the company repeatedly urges that the plaintiff, a lung cancer victim, is barred from suit because the risks of smoking have long been a matter of common public knowledge. On the other hand, the company asserts that it has "never agreed with the Surgeon General's conclusion that smoking has been proven to cause cancer". Having asserted that causation has not been established, Philip Morris cannot argue persuasively that members of the general public know better and, by reason of their superior knowledge, are deprived of legal recourse."

According to Mark Gottlieb, an attorney with the Tobacco Control Resource Center at Northeastern University in Boston, Massachusetts, "I don't think there is anything out there comparable [to Munter's opinion] in the world of tobacco litigation".

Judge Munter's order is available at: 


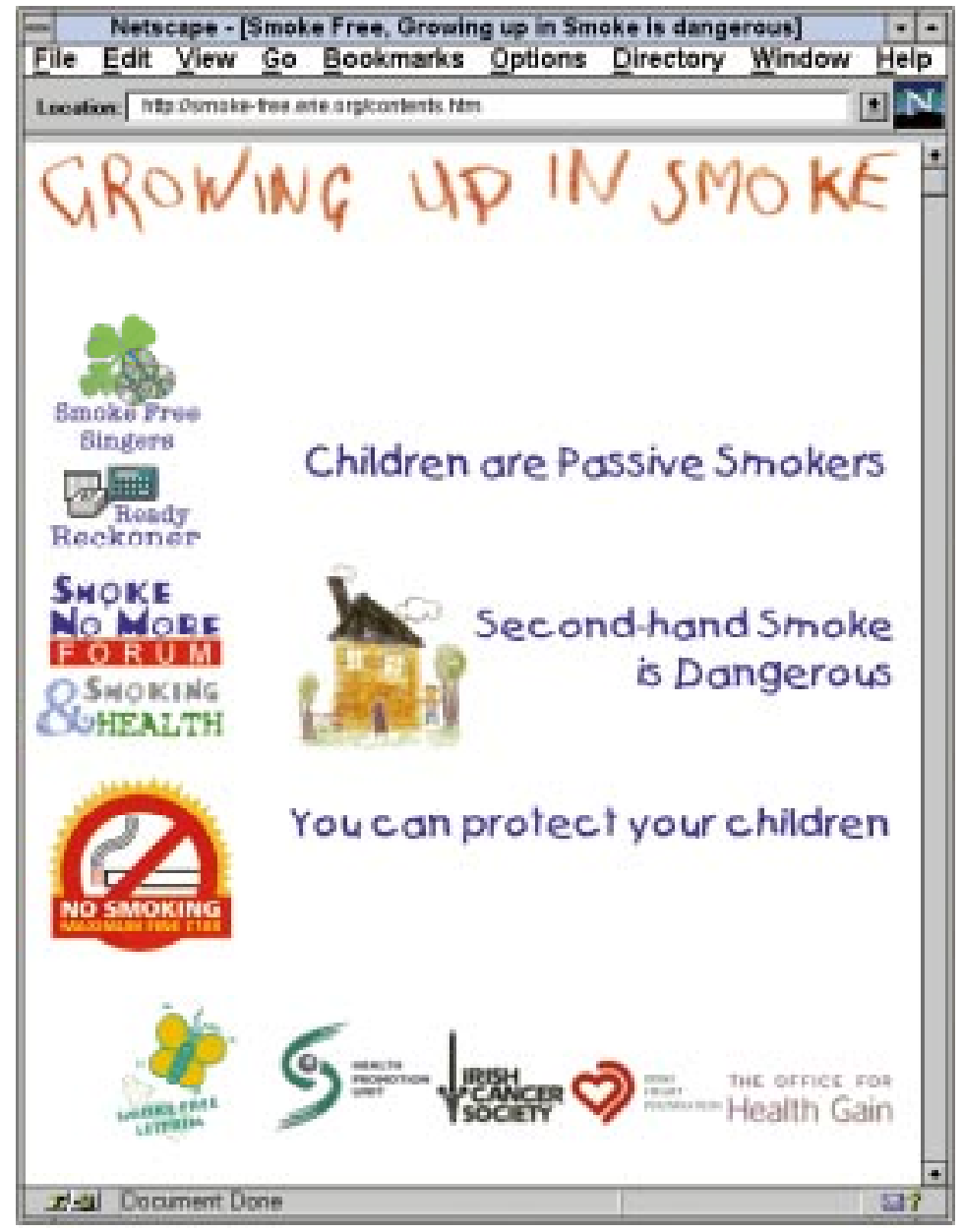

Figure 2 The web site for Growing Up Smoke Free.

J<http://www.callaw.com/stories/ex0407.html>.

Also of substantial interest is a commentary on Judge Munter's order from the Law News Network:

$<$ http://www.lawnewsnetwork.com/stories/A537$1999 \mathrm{Apr} . \mathrm{html}$.

\section{Smoke Signals}

<http://www.smokesignals.org/>

The Smoke Signals web site is a project from the Society of Thoracic Surgeons-the largest thoracic surgical organisation in the world, with over 4100 members.
The web site is designed to inform and educate visitors about the harmful effects of smoking, not through statistics or numbers, but through the power of pictures and real life circumstances.

Through this web site, the society hopes to persuade smokers to quit the habit and prevent others from starting. The society also wants to help visitors encourage loved ones they care about to do the same.

Smoke Signals features interactive video and photographs, enabling visitors to view directly the harmful effect that smoking has on the human body. Photographs of the step by step procedures involved in lung reduction surgery are vividly depicted. In addition, the site offers visitors a place where they can print or email postcards with stop-smoking messages to loved ones who smoke.

\section{The Hong Kong Council on Smoking and} Health

<http://www.info.gov.hk/hkcosh/>

Following the World Health Organisation's recommendations, the Hong Kong Council on Smoking and Health (COSH) was established in 1987 to coordinate measures against tobacco use.

Available in Chinese and English texts, this site hosts several reports and posts current issues related to smoking and health.

Of particular interest is the COSH's report Smoking and passive smoking in children 1998. This survey shows that almost half of Hong Kong's children were living with smokers and that $37 \%$ of boys and $21 \%$ of girls had experimented with smoking by age 13 .

One press release covers the catastrophic epidemic of smoking deaths in China, with three million tobacco-attributable deaths a year expected by the middle of the next century. Another press release shows that the excess risks of coronary heart disease among men smokers are $70 \%$ and women smokers are $170 \%$ in mainland China. In Hong Kong, the excess risks are $244 \%$ and $97 \%$ among men and women smokers respectively. 